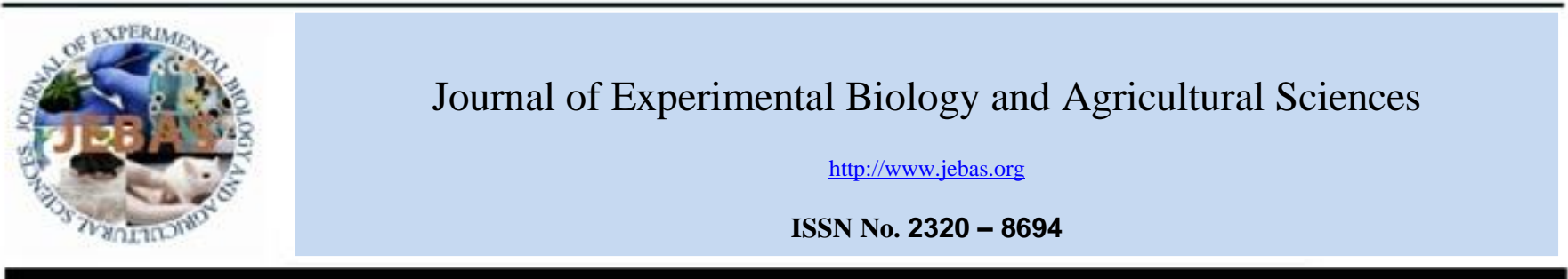

\title{
CRITICAL LIMITS OF SOIL AVAILABLE PHOSPHORUS FOR RAPESEED (Brassica campestris VAR. toria) IN ACIDIC SOILS OF MEGHALAYA
}

\author{
Sanjay Swami, Alok Maurya \\ School of Natural Resource Management, College of Post Graduate Studies, Central Agricultural University, Umiam - 793 103, Meghalaya \\ Received - March 10, 2018; Revision - May 18, 2018; Accepted - July 19, 2018 \\ Available Online - August 10, 2018 \\ DOI: http://dx.doi.org/10.18006/2018.6(4).732.738
}

\author{
KEYWORDS \\ Phosphorus sources and levels \\ Rapeseed \\ Acidic soils \\ Critical limits
}

* Corresponding author

E-mail: sanjayswamionline@yahoo.com (Sanjay Swami)

Peer review under responsibility of Journal of Experimental Biology and Agricultural Sciences.

Production and Hosting by Horizon Publisher India [HPI] (http://www.horizonpublisherindia.in/).

All rights reserved.

\begin{abstract}
A pot culture experiment was conducted at School of Natural Resource Management, College of Post Graduate Studies, Central Agricultural University, Umiam, Meghalaya during Rabi season of 2016-17. The experiment was consisted of 24 treatments viz., 2 types of soil (Alfisol and Inceptisol), 2 sources of $\mathrm{P}$ (single super phosphate and Mussoorie rock phosphate) and 6 levels of $\mathrm{P}(0,30,60,90,120$ and 150 $\mathrm{mg} \mathrm{P} \mathrm{kg}{ }^{-1}$ of soil). Rapeseed (cv. M-27) was raised as test crop. The experiment was conducted in completely randomized design and replicated thrice. The highest mean dry matter yield of rapeseed $\left(16.1 \mathrm{~g} \mathrm{pot}^{-1}\right)$ was recorded with $120 \mathrm{mg} \mathrm{P} \mathrm{kg}^{-1}$ of soil $\left(\mathrm{P}_{5}\right)$. Further increase in the levels of $\mathrm{P}$ by $150 \mathrm{mg}$ $\mathrm{P} \mathrm{kg}^{-1}\left(\mathrm{P}_{6}\right)$ of soil significantly decreased the dry matter yield by $4.6 \%$ over $\mathrm{P}_{5}$. The dry matter yield produced with RP was of lower order as compared to SSP at each levels of P irrespective of soil type. The concentration of $\mathrm{P}$ in plant dry matter of rapeseed increased with each successive levels of $\mathrm{P}$ in both soils and with both of $\mathrm{P}$ sources. The highest soil available $\mathrm{P}\left(64 \mathrm{~kg} \mathrm{ha}^{-1}\right)$ was recorded in Inceptisol with $\mathrm{P}_{6}$ under SSP, whereas the least soil available $\mathrm{P}\left(8.2 \mathrm{~kg} \mathrm{ha}^{-1}\right)$ was recorded in Alfisol with control under RP. The critical limits of available P was established by using LRP model as 38.5 and $31.0 \mathrm{~kg} \mathrm{ha}^{-1}$ through RP and SSP in Alfisol, whereas in Inceptisol, the critical limits values were recorded as 37.0 and $29.5 \mathrm{~kg} \mathrm{ha}^{-1}$ under RP and SSP, respectively.
\end{abstract}

All the article published by Journal of Experimental Biology and Agricultural Sciences is licensed under a Creative Commons Attribution-NonCommercial 4.0 International License Based on a work at www.jebas.org.

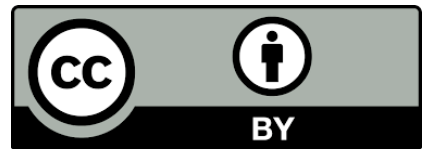




\section{Introduction}

Oilseed crops are second most important crop next to cereals. India is the $4^{\text {th }}$ largest consumer of edible oils after United States of America, China and Brazil (Parcell et al., 2018). Globally, rapeseed and mustard contributes almost 6 percent of global vegetable oil production, 14 percent of vegetable oil imports and 10 per cent of edible oils (Mir et al., 2010). Rapeseed-mustard ranks second in area and production among all the oilseed crops after groundnut in India. It contributes to the area (4.1 M ha) and production $(6.6 \mathrm{Mt})$ of total oilseed and mustard of India with average productivity of $11.82 \mathrm{q} \mathrm{ha}^{-1}$ (Prasad, 2013). It is cultivated in Meghalaya on an area of 9720 ha and production of 9270 tones with productivity of $9.5 \mathrm{q} \mathrm{ha}^{-1}$ with the per capita per day oil availability of just $8.0 \mathrm{~g}$ that is moderate against the national requirement (Anonymous, 2014).

About $81 \%$ soils of this region are acidic in nature out of total cultivated area (Sharma et al., 2006). Acid soil limits the soil phosphorus (P) availability to the crop plants because they have tendency to fix $\mathrm{P}$ as iron and aluminium phosphate (Ryden \& Pratt, 1980). Adequate $P$ supply based on precise assessment of soil $\mathrm{P}$ requirement is therefore crucial to improving crop productivity in the region (Singh et al., 2014). P is essential for energy transformation (fat) especially in oil seed crops and finally, improves the oil content (Fohse et al., 1991). However, at present time, $\mathrm{P}$ recommendation for rape seed crop production in this region is unknown. So keeping these views in the mind, an experiment was conducted to find out critical limits of soil available $\mathrm{P}$ for rapeseed in acid soils of Meghalaya.

\section{Material and Methods}

A pot experiment was conducted at School of Natural Resource Management, College of Post-Graduate Studies, Central Agricultural University, Umiam, Meghalaya during Rabi season of 2016-17. The experiment was consisted of twenty four treatments viz., two types of soil (Alfisol and Inceptisol), two P sources (single super phosphate and Mussoorie rock phosphate) and six levels of $\mathrm{P}\left(\mathrm{P}_{1}=0, \mathrm{P}_{2}=30, \mathrm{P}_{3}=60, \mathrm{P}_{4}=90, \mathrm{P}_{5}=120\right.$ and $\mathrm{P}_{6}=150 \mathrm{mg} \mathrm{kg}^{-1}$ of soil). Rapeseed (cv. M-27) was raised as test crop. The experiment was conducted in completely randomized design and replicated thrice. The critical limits of available $\mathrm{P}$ were determined by using Linear Response Plateau (LRP) Model proposed by Waugh et al. (1973). Only dry matter yield of rapeseed and available $\mathrm{P}$ determined by Bray $\mathrm{P}_{1}$ were used for fitting the LRP model for establishment of critical limits of available $P$. The linear response and plateau lines were established and the point of intersection was used to determine the critical limits of available $\mathrm{P}$.

Two bulk soil samples were collected from the village BhorymBhong (Alfisol) and Umiam (Inceptisol), Ri-Bhoi districts of Meghalaya from 0 to $15 \mathrm{~cm}$ soil depth. The soil sample was dried and ground to pass through $2 \mathrm{~mm}$ stainless steel sieve to remove gravels and other materials for conducting pot culture experiment. Physio-chemical properties of the collected soils were estimated using standard methods as mentioned against each parameter and are presented in Table 1 .

Seventy two plastic pots of $10 \mathrm{~kg}$ capacity were filled with two types of soils after performing sterilization. According to the

Table 1 Physio-chemical properties of experimental soils

\begin{tabular}{|c|c|c|c|c|c|c|}
\hline Parameters & \multicolumn{3}{|c|}{ Soil 1 (Alfisol) } & $\begin{array}{r}\mathrm{S} \\
\text { (Ince }\end{array}$ & $\begin{array}{l}\text { Soil } 2 \\
\text { eptisol }\end{array}$ & Method used \\
\hline Soil texture & \multicolumn{3}{|c|}{ Sandy loam } & $\begin{array}{r}\text { Sanc } \\
1\end{array}$ & $\begin{array}{l}\text { idy clay } \\
\text { oam }\end{array}$ & International pipette method (Olmstead et al., 1930) \\
\hline $\mathrm{pH}$ & \multicolumn{3}{|c|}{4.86} & & 5.02 & pH meter with glass electrode (Piper, 1966) \\
\hline Organic carbon $(\%)$ & \multicolumn{3}{|c|}{1.1} & & 1.3 & Rapid titration method (Walkley \& Black, 1934) \\
\hline $\operatorname{CEC}\left(\right.$ meq $100 \mathrm{~g} \mathrm{soil}^{-1}$ ) & \multicolumn{3}{|c|}{2.8} & & 3.7 & Ammonium acetate saturation method Jackson (1973) \\
\hline Available Nitrogen $\left(\mathrm{kg} \mathrm{ha}^{-1}\right)$ & \multicolumn{3}{|c|}{275.0} & & 350.0 & Alkaline potassium permanganate method (Subbiah \& Asijah, 1956) \\
\hline Available Phosphorus $\left(\mathrm{kg} \mathrm{ha}^{-1}\right)$ & \multicolumn{3}{|c|}{8.0} & & 13.0 & Bray and Kurtz No. 1 method (Bray \& Kurtz, 1945) \\
\hline Available Potassium $\left(\mathrm{kg} \mathrm{ha}^{-1}\right)$ & \multicolumn{3}{|c|}{259.8} & & 280.0 & Neutral Normal Ammonium Acetate Method (Knudsen et al., 1982) \\
\hline Available Sulphur $\left(\mathrm{kg} \mathrm{ha}^{-1}\right)$ & \multicolumn{3}{|c|}{14.3} & & 18.5 & $\mathrm{CaCl}_{2}$-extractable S (Chesnin \& Yien 1951) \\
\hline \multirow{2}{*}{$\begin{array}{l}\text { Available micronutrients } \\
\left(\mathrm{mg} \mathrm{kg}^{-1} \text { soil }\right)\end{array}$} & $\mathrm{Zn}$ & $\mathrm{Cu}$ & Mn & $\mathrm{Fe}$ & $\mathrm{Zn}$ & $\mathrm{Cu} \quad \mathrm{Mn} \quad \mathrm{Fe} \quad$ DTPA Method (Lindsay \& Norvell, 1978) \\
\hline & 0.53 & 2.1 & 3.0 & 12.32 & 0.61 & $\begin{array}{lll}2.5 & 3.45 & 9.81\end{array}$ \\
\hline
\end{tabular}


treatments the amount of $\mathrm{P}$ was supplied through the single super phosphate (SSP) and rock phosphate (RP) and posts were kept in polyhouse. The seed of test crop (rapeseed variety M-27) was obtained from ICAR Research Complex for NEH Region, Barapani, Meghalaya. The crop was sown on $5^{\text {th }}$ November, 2016 and it was harvested on $24^{\text {th }}$ January, 2017 at physiological maturity stage and dry matter yield was recorded. Plant samples were collected from each pot for chemical analysis. The samples were dried in an oven and then grinded thoroughly with grinder and preserved separately in sealed and labelled containers. $0.5 \mathrm{~g}$ oven dried plant samples were digested and the $\mathrm{P}$ concentration in the digested plant samples was determined yellow colour development method using spectrophotometer at $420 \mathrm{~nm}$ wavelength. The uptake of $\mathrm{P}$ by rapeseed was worked out by using the following formula:

$P$ uptake by plant $\left(\mathrm{kg} \mathrm{ha}^{-1}\right)=$ Per cent nutrient concentration in rapeseed $\mathrm{X}$ dry matter yield $\left(\mathrm{t} \mathrm{ha}{ }^{1}\right) \times 10$

The Data obtained from the experiment were subjected to statistical analysis (ANOVA) and significant difference was calculated at 5\% level of significance (Fisher, 1958).

\section{Results and Discussion}

\subsection{Dry matter yield}

The mean plant dry matter yield increased significantly with the increasing levels of $\mathrm{P}$ up to $90 \mathrm{mg}$ of $\mathrm{P} \mathrm{kg}^{-1}$ soil however, the highest mean dry matter yield of rapeseed $\left(16.1 \mathrm{~g} \mathrm{pot}^{-1}\right)$ was recorded with the application of $120 \mathrm{mg}$ of $\mathrm{P} \mathrm{kg}^{-1}$ of soil. Further increase in the dose of $\mathrm{P}$ by $150 \mathrm{mg}$ of $\mathrm{P} \mathrm{kg}^{-1}$ soil significantly decreased the dry matter yield by $4.6 \%$ over $120 \mathrm{mg}$ of $\mathrm{P} \mathrm{kg}^{-1}$ (Table 2). The dry matter yield produced with RP was of lower order as compared to SSP at each levels of P irrespective of soil type. Among various two ways and three way interaction, all the interactions were found to be significant. This enormous response in dry matter yield with the application of $\mathrm{P}$ was due to low available $\mathrm{P}$ status of the experimental soil. It revealed the optimum mean dry matter yield recorded with $90 \mathrm{mg} \mathrm{P} \mathrm{kg}^{-1}$ soil was 2.44 times more than the control where no $\mathrm{P}$ was applied. It also revealed the high intensity of responsiveness of rapeseed crop to $\mathrm{P}$ fertilization

Results of dry matter yield are in agreement with the findings of Singh \& Bishnoi (1994) and Yousaf et al. (2017) who reported

Table 2 Effect of P sources and levels of $\mathrm{P}$ on dry matter yield of rapeseed $\left(\mathrm{g} \mathrm{pot}^{-1}\right)$ in two types of soils

\begin{tabular}{|c|c|c|c|c|c|}
\hline \multirow{2}{*}{$P$ levels $\mathrm{mg} \mathrm{kg}^{-1}$ soil } & \multicolumn{2}{|c|}{ Alfisol } & \multicolumn{2}{|c|}{ Inceptisol } & \multirow{2}{*}{ Mean } \\
\hline & $\mathrm{RP}$ & SSP & $\mathrm{RP}$ & SSP & \\
\hline 0 & 5.57 & 6.00 & 7.02 & 7.20 & 6.45 \\
\hline 30 & 9.34 & 10.30 & 10.77 & 11.89 & 10.58 \\
\hline 60 & 12.12 & 13.20 & 14.14 & 15.61 & 13.77 \\
\hline 90 & 14.21 & 15.00 & 16.13 & 17.68 & 15.76 \\
\hline 120 & 14.44 & 15.20 & 17.02 & 17.81 & 16.11 \\
\hline 150 & 14.12 & 14.90 & 15.80 & 16.65 & 15.37 \\
\hline $\mathrm{RP}$ & 12.56 & Alfisol & 12.03 & & \\
\hline SSP & 13.45 & Inceptisol & 13.98 & & \\
\hline S.E $(m) \pm$ & 0.14 & & & & \\
\hline $\mathrm{CD}(\mathrm{p}=0.05)$ & 0.39 & & & & \\
\hline \multirow{2}{*}{\multicolumn{2}{|c|}{ For Source of P and Soils }} & \multicolumn{4}{|c|}{ Interaction } \\
\hline & & S x So & $\mathrm{S} \times \mathrm{L}$ & So $\mathrm{x} \mathrm{P}$ & S $x$ So $x \mathrm{~L}$ \\
\hline S.E $(\mathrm{m}) \pm$ & 0.08 & 0.11 & 0.19 & 0.19 & 0.28 \\
\hline $\mathrm{CD}(\mathrm{p}=0.05)$ & 0.23 & 0.32 & 0.55 & 0.55 & 0.78 \\
\hline
\end{tabular}

RP: Rock Phosphate, SSP: Single Super Phosphate, S: Sources of P, So: Soils, L: Levels of P

Journal of Experimental Biology and Agricultural Sciences http://www.jebas.org 
that the $\mathrm{P}$ application to the soil, varying from low to high in available $\mathrm{P}$, increased dry matter yield of sunflower and rapeseed, respectively. The interaction between different levels of applied $\mathrm{P}$ and different rapeseed growing soils of Meghalaya was significant in dry matter yield of rapeseed. It depicted the $\mathrm{P}$ deficiency of soil and high response of $\mathrm{P}$ application in rapeseed. These results are in conformity with those reported by Tyagi \& Rana (1992) who observed that with the application of $\mathrm{P}$ fertilizer, the yield of mustard crop significantly increased up to $80 \mathrm{~kg} \mathrm{P}_{2} \mathrm{O}_{5}$ ha $^{-1}$ which was at par with $100 \mathrm{~kg} \mathrm{P}_{2} \mathrm{O}_{5} \mathrm{ha}^{-1}$. Similar results were also reported by Prabhuraj et al. (1993) in sunflower.

\subsection{Phosphorus content}

Data from the Table 3 revealed that there was a significant increase in concentration of $\mathrm{P}$ by different sources with the increasing levels of applied $\mathrm{P}$ in two rapeseed growing acidic soils of Meghalaya. The lowest mean of $\mathrm{P}$ content ( 0.15 per cent) was recorded in control where no $\mathrm{P}$ fertilizer was applied, which was significantly increased with the progressive increase in the doses of applied $\mathrm{P}$ up to $150 \mathrm{mg} \mathrm{P} \mathrm{kg}{ }^{-1}$. The concentration of $\mathrm{P}$ at each respective levels of applied $\mathrm{P}$ was higher in Inceptisol as compared to Alfisol. The highest mean $\mathrm{P}$ concentration was observed in Inceptisol (0.35 per cent) with SSP application whereas in Alfisol it was recorded ( 0.30 per cent). A glance of the data presented in Table 3 revealed that there was a significant increase in concentration of $\mathrm{P}$ with the increasing levels of applied P. Among various two way and three way interactions, all the interactions were found to be significant.

This increasing $\mathrm{P}$ concentration might be due to the availability of more $\mathrm{P}$ in soils with the application of $\mathrm{P}$ as well as due to initial available P status in the experimental soils. Singh et al. (1997) and Yousaf et al. (2017) also observed that the concentration of P was significantly improved in both straw and seed of sunflower and rapeseed, respectively upon the increased levels of applied P. Similar results were also obtained by Schultz et al. (2018) for sunflower in North Dakota. The concentration of $\mathrm{P}$ was significantly lower in plants grown in Alfisol as compared to Inceptisol. The lower concentration of $\mathrm{P}$ is due to less native soil $\mathrm{P}$ in these soils.

Table 3: Effect of $\mathrm{P}$ sources and levels of $\mathrm{P}$ on $\mathrm{P}$ content $(\%)$ of rapeseed in two types of soils

\begin{tabular}{|c|c|c|c|c|c|}
\hline \multirow{2}{*}{ P levels } & \multicolumn{2}{|c|}{ Alfisol } & \multicolumn{2}{|c|}{ Inceptisol } & \multirow{2}{*}{ Mean } \\
\hline & $\mathrm{RP}$ & SSP & RP & SSP & \\
\hline 0 & 0.12 & 0.14 & 0.16 & 0.18 & 0.15 \\
\hline 30 & 0.14 & 0.17 & 0.21 & 0.23 & 0.19 \\
\hline 60 & 0.18 & 0.20 & 0.25 & 0.27 & 0.23 \\
\hline 90 & 0.24 & 0.25 & 0.28 & 0.31 & 0.27 \\
\hline 120 & 0.27 & 0.29 & 0.30 & 0.33 & 0.30 \\
\hline 150 & 0.28 & 0.30 & 0.31 & 0.35 & 0.31 \\
\hline $\mathrm{RP}$ & 0.23 & Alfisol & 0.22 & & \\
\hline SSP & 0.25 & Inceptisol & 0.26 & & \\
\hline $\mathrm{S} . \mathrm{E}(\mathrm{m}) \pm$ & 0.01 & & & & \\
\hline $\mathrm{CD}(\mathrm{p}=0.05)$ & 0.02 & & & & \\
\hline \multirow{2}{*}{\multicolumn{2}{|c|}{ For Source of $\mathrm{P}$ and Soils }} & \multicolumn{4}{|c|}{ Interaction } \\
\hline & & S x So & $\mathrm{S} \times \mathrm{L}$ & So $\mathrm{x} P$ & S $x$ So $x \mathrm{~L}$ \\
\hline $\mathrm{S} . \mathrm{E}(\mathrm{m}) \pm$ & 0.001 & 0.01 & 0.01 & 0.01 & 0.01 \\
\hline $\mathrm{CD}(\mathrm{p}=0.05)$ & 0.01 & 0.02 & 0.03 & 0.03 & 0.04 \\
\hline
\end{tabular}

RP: Rock Phosphate, SSP: Single Super Phosphate, S: Sources of P, So: Soils, L: Levels of P

Journal of Experimental Biology and Agricultural Sciences http://www.jebas.org 
Table 4 Effect of $\mathrm{P}$ sources and levels of $\mathrm{P}$ on post-harvest $\mathrm{P}$ availability in two types of soils

\begin{tabular}{|c|c|c|c|c|c|}
\hline \multirow{2}{*}{ P levels } & \multicolumn{2}{|c|}{ Alfisol } & \multicolumn{2}{|c|}{ Inceptisol } & \multirow{2}{*}{ Mean } \\
\hline & $\mathrm{RP}$ & SSP & $\mathrm{RP}$ & SSP & \\
\hline 0 & 8.2 & 9 & 10 & 12 & 9.8 \\
\hline 30 & 21.7 & 25 & 19 & 28 & 23.43 \\
\hline 60 & 33.3 & 36 & 31 & 38 & 34.58 \\
\hline 90 & 42.6 & 47 & 42 & 49 & 45.15 \\
\hline 120 & 48 & 52 & 52 & 57 & 52.25 \\
\hline 150 & 54 & 58 & 60 & 64 & 59 \\
\hline $\mathrm{RP}$ & 35.15 & Alfisol & 36.23 & & \\
\hline SSP & 39.58 & Inceptisol & 38.5 & & \\
\hline $\mathrm{S} . \mathrm{E}(\mathrm{m}) \pm$ & 1.01 & & & & \\
\hline $\mathrm{CD}(\mathrm{p}=0.05)$ & 2.87 & & & & \\
\hline \multirow{2}{*}{\multicolumn{2}{|c|}{ For Source of P and Soils }} & \multicolumn{3}{|c|}{ Interaction } & \\
\hline & & S x So & $\mathrm{S} \times \mathrm{L}$ & So $\mathrm{x} \mathrm{P}$ & S x So $x \mathrm{~L}$ \\
\hline S.E(m) \pm & 0.58 & 0.82 & 1.43 & 1.43 & 2.02 \\
\hline $\mathrm{CD}(\mathrm{p}=0.05)$ & 1.66 & 2.34 & 4.06 & 4.06 & 5.74 \\
\hline
\end{tabular}

RP: Rock Phosphate, SSP: Single Super Phosphate, S: Sources of P, So: Soils, L: Levels of P

\subsection{Available Soil phosphorus}

The mean of available $\mathrm{P}$ increased significantly with the increasing levels of $\mathrm{P}$ up to $150 \mathrm{mg} \mathrm{P} \mathrm{kg}^{-1}$ soil, however, the highest mean available $\mathrm{P}$ after harvest of rapeseed $\left(59 \mathrm{~kg} \mathrm{ha}^{-1}\right)$ was recorded from the pots treated with $150 \mathrm{mg} \mathrm{P} \mathrm{kg}^{-1}$ of soil. Among various two way and three way interactions, all the interactions were found to be significant. Data related to postharvest available $\mathrm{P}$ provided in Table 4 . The possible reason about the post-harvest available $\mathrm{P}$ may be due to low phosphorus use efficiency. In general P use efficiency is $10-20 \%$ of the soil applied phosphorus. Similar trend was also reported by Yadav et al. (2015) and Yousaf et al. (2017).

\subsection{Critical limits of soil available $P$}

In order to demarcate the soils on the basis of their responsiveness and non-responsiveness or relatively less responsiveness, the critical limits of available $\mathrm{P}$ were determined. The Linear
Response Plateau (LRP) model proposed by Waugh et al. (1973) was employed to establish the critical limit of available $\mathrm{P}$ for predicting the response of applied P fertilizer to rapeseed (cv. M27). The response to each nutrient all interpreted separately by using the threshold and plateau yield levels in this model. The application of nutrient results in yield response having a starting point i.e. threshold yield and ending point i.e. plateau yield. There was significant relationship between dry matter yield and available $\mathrm{P}$ determined by Bray's $\mathrm{P}_{1}$ soil test method (Bray \& Kurtz, 1945). The only dry matter yield and available $P$ determined by Bray $\mathrm{P}_{1}$ were used for fitting the LRP model for establishment of critical limits of available $P$. The linear response and plateau lines were established and the point of intersection was used to determine the critical limits of available P. The critical limits of available P presented graphically in Figure 1, 2, 3 and 4.

There were positive relationship between dry matter yield and available $\mathrm{P}$ determined by Bray's $\mathrm{P}_{1}$ soil test method. Therefore, 


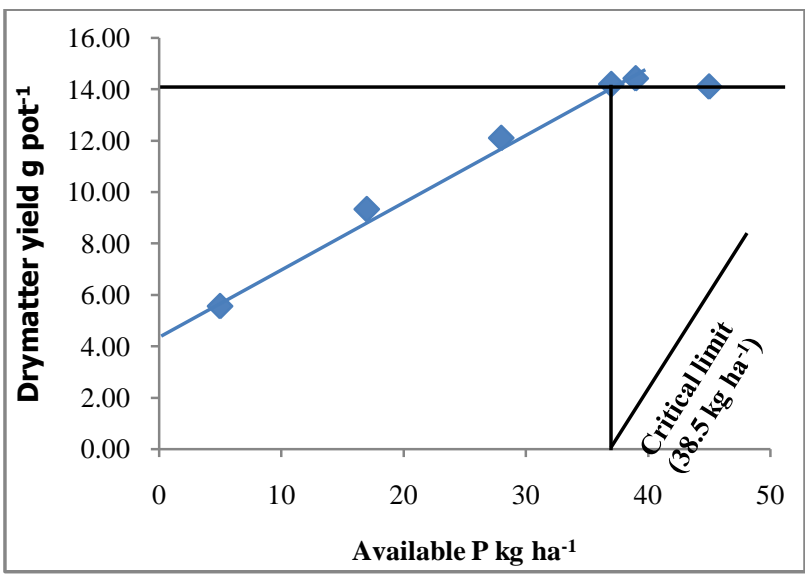

Figure 1 Critical limit of available $\mathrm{P}$ for Rapeseed in Alfisol under RP $\left(\mathrm{kg} \mathrm{ha}^{-1}\right)$

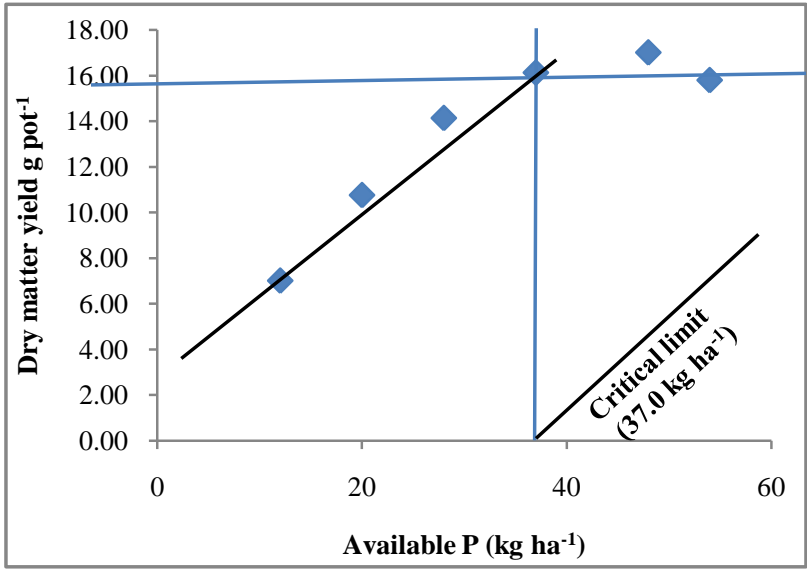

Figure 3 Critical limit of available $P$ for Rapeseed in Inceptisol under RP $\left(\mathrm{kg} \mathrm{ha}^{-1}\right)$

only dry matter yield and Bray's $\mathrm{P}_{1}$ were used for fitting the LRP model for establishment of critical limits of available $\mathrm{P}$ in acidic soils of Meghalaya. The critical limits of available $\mathrm{P}$ for rapeseed (cv. M-27) were established by Bray's $\mathrm{P}_{1}$ soil test for Inceptisol and Alfisol, respectively. The critical limit of $\mathrm{kg} \mathrm{ha}^{-1}$ by Bray's $\mathrm{P}_{1}$ soil test in Inceptisol and Alfisol for the rapeseed crop in the present study was higher than $10.00 \mathrm{~kg}$ Olsen's $\mathrm{P} \mathrm{ha}^{-1}$ for ground nut crop reported by Patel et al. (1992). However, Singh \& Singh (1983) reported that the critical limits of Olsen's extractable P for bajra and barley were 12.7 and $12.2 \mathrm{~kg} \mathrm{Pha}^{-1}$ respectively.

\section{Conclusion}

The application of $\mathrm{P}$ at lower levels resulted in significant increase in dry matter yield of rapeseed under both the $\mathrm{P}$ sources,

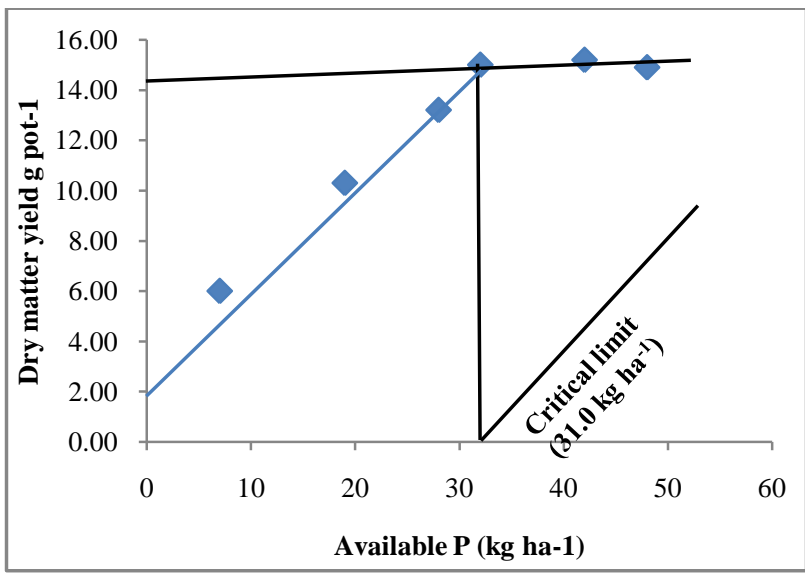

Figure 2 Critical limit of available $\mathrm{P}$ for Rapeseed in Alfisol under SSP $\left(\mathrm{kg} \mathrm{ha}^{-1}\right)$

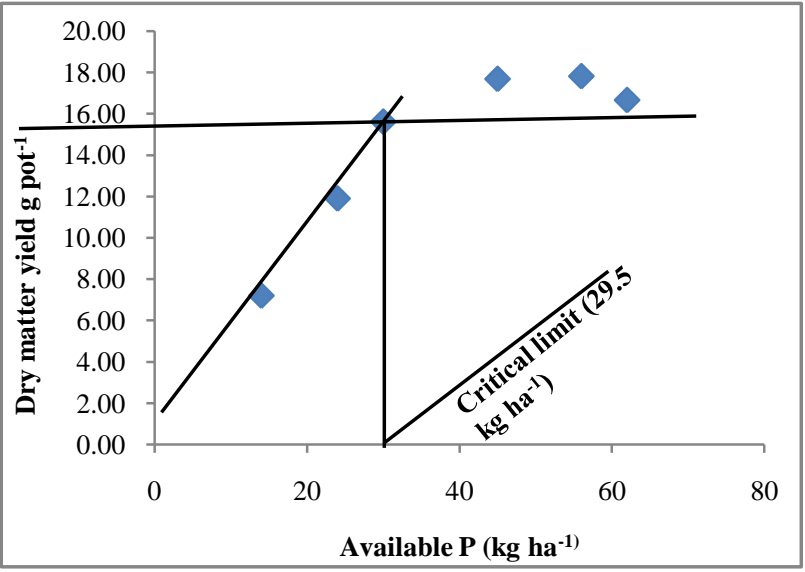

Figure 4 Critical limit of available $\mathrm{P}$ for Rapeseed in Inceptisol under SSP $\left(\mathrm{kg} \mathrm{ha}^{-1}\right)$

irrespective of soils. The significant increase in dry matter yield with the application of $\mathrm{P}$ was due to the low $\mathrm{P}$ available status of the experimental soils and high responsiveness of rapeseed to $\mathrm{P}$ application. The application of $\mathrm{P}$ with 30,60 and $90 \mathrm{mg} \mathrm{P} \mathrm{kg-1}$ soil significantly and markedly increased the dry matter yield of rapeseed crop in Inceptisol and Alfisol. The P concentration increased significantly and progressively with the increasing levels of applied P. There was successive increase in P absorption by the rapeseed crop with each levels of increment of applied P. The critical limit of available $\mathrm{P}$ for rapeseed were established using Linear Response and Plateau (LRP) model as $38.5 \mathrm{~kg} \mathrm{P}^{-1}$ under RP and $31.0 \mathrm{~kg} \mathrm{ha}^{-1}$ under SSP in Alfisol, whereas in Inceptisol, the critical limits of available $\mathrm{P}$ were established as $37.0 \mathrm{~kg} \mathrm{Pha}^{-1}$ under RP and $29.5 \mathrm{~kg} \mathrm{ha}^{-1}$ under SSP. The present investigation indicated that below these critical limits in 
respective acidic soils, farmer may get definite response to applied $\mathrm{P}$ through respective $\mathrm{P}$ sources and above these critical limits, and they may get very little response or may not get response at all. Therefore, the farmers will have to apply higher $\mathrm{P}$ fertilizer doses in these soils for obtaining the optimum yield of rapeseed.

\section{Conflict of Interest}

The authors declare that there is no conflict of interest regarding the publication of this research paper.

\section{References}

Anonymous (2014) Statistical Abstract Meghalaya. Directorate of Economics and Meghalaya, Shillong.

Bray RH, Kurtz LT (1945) Determination of total, organic and available forms of phosphorus in soils. Soil Science 59:39-46.

Chesnin L, Yien CH (1951) Turbidimetric determination of available sulfates. Soil Science Society of America Journal 15:149-151.

Fisher PA (1958) Statistical Methods of Research Workers. Oliver and Boyd, London.

Fohse D, Claassen N, Jungk A (1991) Phosphorus efficiency of plants. Significance of root radius, root hairs and cation-anion balance for phosphorus influx in seven plant species. Plant and Soil 132:261272.

Jackson ML (1973) Soil Chemical Analysis. Prentices Hall of India Pvt. Ltd., New Delhi, pp: 186-192.

Knudsen D, Paterson GA, Pratt PF (1982) Lithium, sodium and potassium. In: Page AL, Miller RH, Keeney DR (Eds.) Methods of Soil Analysis. Part II, $2^{\text {nd }}$ edn. Madison, Wisconsin, pp. 225-246.

Lindsay WL, Norvell WA (1978) Development of a DTPA Soil Test for Zinc, Iron, Manganese, and Copper. Soil Science Society of America Journal 42:421-428.

Mir MR, Mobin M, Khan NA, Bhat MA, Lone NA, Bhat KA, Razvi SM, Wani SA, Wani N, Akhter S, Rashid S, Masoodi NH, Payne WA (2010) Effect of fertilizers on yield characteristics of mustard (Brassica juncea L. Czern and Coss). Journal of Phytology 2: 20-24.

Olmstead, LB, Alexander LT, Middleton HE (1930) A Pipette method of mechanical analysis of soils based on Improved Dispersion Procedure. United States Department of Agriculture, Washington, D.C., Pp.3-18,

Parcell J, Kojima Y, Roach A, Cain W (2018) Global Edible Vegetable Oil Market Trends. Biomedical Journal of Science and Technology Research 2:1-10.

Patel MS, Zalawadia NM, Sutaria GS, Patel AG (1992) Response of groundnut to phosphorus and its critical limits in vertisol of Surastra. Journal of Indian Society of Soil Science 40:97-100.
Piper CS (1966) Soil and Plant Analysis. Hans Publishers, Bombay.

Prabhuraj OK, Badigar MK, Manure GR (1993) Growth and yield of sunflower as influenced by levels of P, S and Zn. Indian Journal of Agronomy 38:427-430.

Prasad R (2013) Field Crops Production, Commercial Crops, V-II, Indian Council of Agricultural Research, New Delhi, p: 80-118.

Ryden JE, Pratt PF (1980) Phosphorus removal from wastewater applied to land. Hilgardia. 48:1-36.

Schultz E, Sutter TD, Sharma L, Endres G, Ashley R, Bu H, Markell S, Kraklau A, Franzen D (2018) Response of Sunflower to Nitrogen and Phosphorus in North Dakota. Agronomy Journal 110:685-695.

Sharma PD, Baruah TC, Maji AK, Patiram (2006) Management of acid soils of NEH Region. Indian Council of Agricultural Research, Krishi Anusandhan Bhavan, Pusa Campus, New Delhi, Pp: 45-60.

Singh AK, Bordoloi LJ, Kumar, M, Hazarika S, Parmar B (2014) Land use impact on soil quality in eastern Himalayan region of India. Environment Monitoring and Assessment 186:2013-2024.

Singh B, Bishnoi SR (1994) Response of sunflower to phosphorus application of soils differing in available phosphorus status. Journal of Indian Society of Soil Science 42:331-332.

Singh R, Sharma RK, Singh M (1997) Studies on soil P and response of sunflower to applied P on some soils of Haryana. Journal of Indian Society of Soil Science 45:301-305.

Singh R, Singh M (1983) Critical limits of available P for bajra and barley in Sierozem soils of Haryana. Journal of Research of Haryana Agricultural University 13:238-244.

Subbiah BV, Asija GL (1956) A rapid procedure for the estimation of available nitrogen in soils. Current Science 25:259-260.

Tyagi MK, Rana NS (1992) Response of mustard cultivars to phosphorus. Indian Journal of Agronomy 37:841-842.

Walkley A, Black IA (1934) An examination of the method for determining soil organic matter and a proposed modification of the chromic acid titration method. Soil Science 37:29-38.

Waugh DL, Cate RB Jr, Nelson LA (1973) Discontinuous model for rapid correlation, interpretation and utilization of soil analysis and fertilizer response data. Tech. Bull. No. 7, ISFEI Series, North Carolina State University, Releigh, W.C.

Yadav GS, Datta M, Babu S, Saha P, Singh R (2015) Effect of sources and levels of phosphorus on productivity, economics, nutrient acquisition and phosphorus-use efficiency of groundnut (Arachis hypogaea) under hilly ecosystems of North-East India. Indian Journal of Agronomy 60:307-311.

Yousaf M, Li J, Lu J, Ren T, Cong R, Fahad S, Li X (2017) Effects of fertilization on crop production and nutrient-supplying capacity under rice-oilseed rape rotation system, Scientific Reports 7:1270. 